\title{
Solitary Circumscribed Neuroma
}

National Cancer Institute

\section{Source}

National Cancer Institute. Solitary Circumscribed Neuroma. NCI Thesaurus. Code

C121681.

A benign peripheral nerve sheath tumor characterized by the presence of Schwann cells, axons, and perineurial fibroblasts. It usually arises from the skin of the head and neck or the oral mucosa. It presents as a solitary and painless nodular mass. 